\title{
Reconstructing Iconic Experiments in Electrochemistry: Experiences from a History of Science Course
}

\author{
Per-Odd Eggen $\cdot$ Lise Kvittingen $\cdot$ Annette Lykknes $\cdot$ Roland Wittje
}

Published online: 1 April 2011

(C) The Author(s) 2011. This article is published with open access at Springerlink.com

\begin{abstract}
The decomposition of water by electricity, and the voltaic pile as a means of generating electricity, have both held an iconic status in the history of science as well as in the history of science teaching. These experiments featured in chemistry and physics textbooks, as well as in classroom teaching, throughout the nineteenth and twentieth centuries. This paper deals with our experiences in restaging the decomposition of water as part of a history of science course at the Norwegian University of Science and Technology, Trondheim, Norway. For the experiment we used an apparatus from our historical teaching collection and built a replica of a voltaic pile. We also traced the uses and meanings of decomposition of water within science and science teaching in schools and higher education in local institutions. Building the pile, and carrying out the experiments, held a few surprises that we did not anticipate through our study of written sources. The exercise gave us valuable insight into the nature of the devices and the experiment, and our students appreciated an experience of a different kind in a history of science course.
\end{abstract}

\section{Introduction}

This is a story describing the challenge and entertainment of restaging the experiment to decompose water using electric energy from a voltaic pile in a history of science course.

This experiment appeared both untidy and unpredictable; a common aspect of science in practice, but which nevertheless is under-reported by scientists in general, and by historians of science who study historical artefacts. The scientist, as well as the historian, readily learns that an account of a messy personal experience is not acceptable in a "professional" publication (Corn 1996, pp. 16-29; Wittje 2003). Our paper aims to illustrate at least some of this coincidental and personal experience.

P.-O. Eggen · L. Kvittingen $(\bowtie) \cdot$ A. Lykknes

Department of Chemistry, Norwegian University of Science and Technology,

7491 Trondheim, Norway

e-mail: lise.kvittingen@nt.ntnu.no

R. Wittje

History of Science Unit, University of Regensburg, 93040 Regensburg, Germany 
The instrument used for the decomposition of water was a demonstration instrument from the historical collection at the Department of Physics of the Norwegian University of Science and Technology. The voltaic pile we made was inspired by Volta's description from 1800. From an educational perspective it is worth noting that the experiments described here cover two fundamental aspects of electrochemistry; the production of chemical reactions from electricity in electrolytic cells (with the water splitting apparatus) and the production of electricity from chemical reactions in galvanic cells (with the voltaic pile).

\section{A Course and Historical Collections}

At the Departments of Physics and Chemistry at the Norwegian University of Science and Technology ${ }^{1}$ we have in the last ten years managed to collect historical scientific instruments and other objects, as well as archive material from the former institution, the Norwegian Institute of Technology, which was established in 1910. In 2006 we started a course in the History of Science in which we decided to reproduce some classical experiments with instruments from these collections. Our motivation was mixed and at least four aspects were compelling. The first was that by displaying instruments and experiments in a history of science course we would illustrate the material cultures and contexts which otherwise are "illegible to those who know how to read only writing". The history of experiments, scientific instruments and scientific practice has been a central topic for the history of science since the so-called Pragmatic Turn of the science studies in the 1980s and 1990s. ${ }^{2}$ More recently, material cultures of science have come into prominence with the rise of cultural studies of science on the one hand, and the (re)discovery of material heritage and historical collections at universities and other scientific institutions on the other hand. ${ }^{3}$ Through restaging of historical experiments past challenges and confusions could also be reopened and reflected on (Cavicchi 2006). ${ }^{4}$ Second, we needed to activate our collections as they compete with modern instruments for space in the science departments. Third, we were curious about our collections and reconstructing experiments is one way to obtain more intimate knowledge. Last, but not least, we would enjoy ourselves while reconstructing experiments. We acknowledge that professionals from museums might feel discomfort on behalf of our objects, but we believe that our collections should be activated into teaching and research, nevertheless preservation is also our concern.

\footnotetext{
${ }^{1}$ NTNU was established in 1996 as a further development of the University of Trondheim (UNiT). UNiT was established as a result of a merger between the Norwegian Institute of Technology (NTH), The College of Arts and Sciences (AVH) and the Museum of Natural History and Archaeology. For a perspective on the founding of NTH, see Wittje (2006).

${ }^{2}$ Some of the central publications for the "Pragmatic Turn" in history of science and science studies are Hacking (1983), Shapin and Schaffer (1985), Galison (1987), Pickering (1992) and Buchwald (1995).

${ }^{3}$ An example for the interest in scientific objects inspired by cultural studies is Daston (2004). In the last decade, a number of national as well as international initiatives, networks, and conferences have been organised to protect scientific heritage at universities, and to mobilise it for teaching, research and for public exhibitions. See Lourenço (2005) about historical collections at universities in Europe. Rittenhouse, the Journal for the American Scientific Instrument Enterprise, has recently published a special issue on Scientific Instrument Collections in Universities: Teaching with University Collections (Rittenhouse, Vol. 22, No. 2, 2008).

${ }^{4}$ The method of replicating historical experiments as an experimental method in history of science has been developed by the Research Group on Higher Education and History of Science of the University of Oldenburg, See Heering (2000), and Sibum (2000).
} 


\section{A Modest Instrument, a Classical Experiment, an Icon?}

We had decided to air one of our instruments, but which one? From the historical physical cabinet there were beauties to choose between, such as the polariometer, goniometer, spectrophotometer, electrometer, torsion balance or refractometer used in teaching and research at our institution. After some pondering we chose a modest little instrument used in teaching, which was appropriate as our course is mainly aimed at prospective science teachers, namely an instrument for demonstrating the decomposition of water using electricity made of a glass vial with two inverted test-tubes with platinum electrodes, as seen in Fig. 2. We could think of several reasons for choosing this experiment. The electrical decomposition is a classical experiment with a unique history. It is an iconic experiment in both physics and chemistry teaching, although both the purpose and conclusions vary between these disciplines. For chemists, the experiment is closely related to the constitution of chemical substances and the quantitative relation of hydrogen and oxygen in water. It would be an exaggeration to claim that physicists whole-heartedly share this view. For the physicists the canonical role of the experiment in their teaching is rather related to the chemical effect of electricity and thereby to the very nature of electricity itself. Another use of the decomposition apparatus is as a voltameter. In a voltameter the decomposition is no longer the object of investigation or the epistemic thing (Rheinberger 1997); it becomes a measurement principle to measure current.

\section{A Long History}

Electrolysis of water has a history of more than 200 years. Our instrument, dating from 1910 , is nicely set in the middle of that period. At the beginning of the nineteenth century electricians often performed this experiment after Paets van Troostwyk and Deiman (1789), Pearson (cited in Faraday 1849, p. 92), Carlisle and Nicholson (Nicholson 1800) and Hildebrand (1805) had pioneered the work. The experiment was part of the important debate on the very nature of water and its composition. In the course of the nineteenth-century, it became widely disseminated and a remarkable example can be found in Les Merveilles de la Science of Louis Figuier (1868). After the establishment of the Norwegian Institute of Technology in 1910, electrolysis of water soon became part of the regular teaching (Fig. 1). It continued to enjoy a prominent place in Norwegian chemistry textbooks from the first decades of the twentieth-century (Bruun 1920, pp. 17-18) ${ }^{5}$ and even figures in today's American textbooks on general chemistry (Chang 1994; Zumdahl 2003, p. 857) as well as in the Journal of Chemical Education (Eggen and Kvittingen 2004; Heideman and Wollaston 1986; Zhou 1996). Although less common in physics textbooks today, the experiment appeared regularly in textbooks between 1920 and 1970 (Arnljot 1968, pp. 165-166; Bruun and Devik 1965, p. 126; Holmsen and Strøm 1942, p. 77; Holtsmark 1925, pp. 116-117; Jansen and Eskeland 1946, pp. 170-171). The purpose of decomposing water has changed over time, from being part of the evidence that water consists of hydrogen and oxygen (Pearson as cited in Faraday 1849; Hildebrand 1805; Troostwyk and Deiman 1789), to a proof of the law of definite proportions, at least in Norwegian textbooks (Bruun 1920, pp. 17-18; Holmsen and Strøm 1942, p. 77; Jansen and Eskeland 1940, pp. 101-102; Kåsa

\footnotetext{
${ }^{5}$ Bruun authored textbooks for gymnasiums both in chemistry and physics; both held large market shares. Bruun's chemistry text appeared regularly from 1914 until the end of the 1970s (see Sverre Bruun og Olaf Devik - et larebokjubileum 1964).
} 


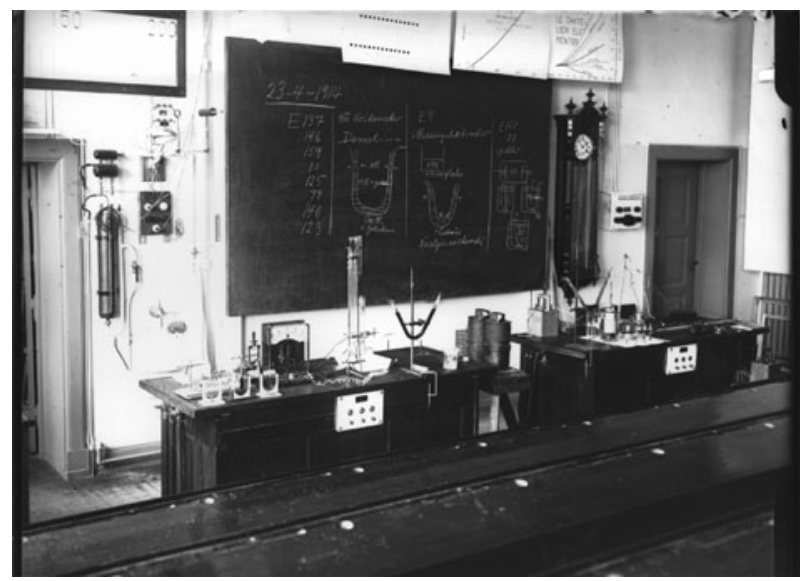

Fig. 1 Demonstration experiments in the physics lecture, 23.4.1914, at the Norwegian Institute of Technology. The topic is electrolysis. Courtesy of the State Archive in Trondheim (Statsarkivet i Trondheim), Archive for the Norwegian Institute of Technology, Department of Physics, Ua:1 and Uc:1

and Strøm 1939, pp. 111-112) and finally as part of general electrolysis (Chang 1994, pp. 793-794; Zumdahl 2003, p. 857). For the physicist, the voltameter represents a quantitative method to measure current. Judging from the catalogues of Max Kohl (pp. 615-617) and Leybold (1913, pp. 702-707), which included 10-15 examples of the voltameter, the decomposing of water was a popular activity around 1900. Even a Norwegian school supplier had seven varieties in its catalogue (Jacobsen 1903, pp. 66-68).

\section{A Norwegian Context}

Our apparatus, although not particularly beautiful, was made by the Norwegian instrument maker Ole Georg Gjøsteen (1854-1936) (NBL 1929). Gjøsteen, a man of considerable initiative, combined political aspirations, in particular on school issues in the Labour party, with a life-long job as an instrument maker and janitor at the University of Oslo. To add to his income he started a company to supply educational equipment to schools as the university sector was a meagre market with just one university in Norway at the time. Gjøsteen's life and the water splitting apparatus in our collection link our institution at the fringe of both Europe and Norway to the central institutions, theories and experiments within science and chemistry, and in this particular context to the electrolysis of water, both as a discovery in the early nineteenth-century and as a demonstration experiment 100 years later. Gjøsteen is also a contributor to science and teaching who is normally ignored, and who we through this setting were able to embrace, thus he was, as such, also part of our historical presentation.

\section{Everybody Knows It}

Electrolysis of water is an experiment that 'everybody' has conducted and 'everybody' apparently knows will work, from Primo Levi in his beautiful book The Periodic Table, where he describes the experiment as "an experiment with a guaranteed result" (Levi 1989, 
pp. 21-28), to a relatively recent description in Journal of Chemical Education in which the author claims that only a truly sheltered student has not seen this as a classroom demonstration at least once. He further says that we (the teachers) know that "exactly 2 mol of hydrogen gas $\left(\mathrm{H}_{2}\right)$ evolve at the cathode for every mole of oxygen $\left(\mathrm{O}_{2}\right)$ produced at the anode" (a statement which we also found in textbooks) and that "the measured volumes of evolved gas nicely illustrate several important relationships: stoichiometry, combining volumes (Gay-Lussac), the Avogadro hypothesis, Faraday's laws, etc." (Kelsh 1985). So, this is apparently a simple experiment with a predictable outcome and therefore it was a good candidate for our reconstruction and the airing of an object from our collection. We also had some previous personal experience with the electrolysis of water and were thus relatively confident that we would succeed in reconstructing the experiment using Gjøsteen's apparatus. Retrospectively, we are amazed we were that ignorant considering that some of us are relatively seasoned experimentalists with enough experience to know that no experiment is straightforward, is without surprises and will work immediately.

In order to conduct the electrolysis we needed an electric source. The batteries used with Gjøsteen's instrument were gone and modern dry cells seemed awfully out of place. As electrolysis of water is so closely connected to the voltaic pile, we decided to reconstruct one. Thus, at this point we were expanding our historical collection with a new replica of a historical object. One might well argue that it is anachronistic to use a voltaic pile, dating from the early 1800 s, together with our decomposition apparatus from 1910 . However a quick look in our instrument catalogues reveals that voltaic piles were still common instruments for teaching purposes in the early twentieth-century, even though they had disappeared from research and other technical applications long before (Kohl 1926-1928).

\section{An Electric Source: Another Icon}

The voltaic pile, similarly to the splitting of water by electric current, is an icon in the history of experimental chemistry and physics. These two experiments are often also combined. Volta's paper (Volta 1800) to Sir Joseph Banks at the Royal Society, dated 20th March 1800, in which he describes the construction of the pile, was read by Carlisle, who shared it with Nicholson (Pancaldi 2003, pp. 212-221), even before it was announced to the Royal Society on 26th July 1800. Within months, the construction of the pile was disseminated to different milieus and to various European cities. This was very much associated with the pile as a powerful machine for chemical purposes, initially important in the discussion of the composition of water, and soon also in the isolation of new elements (Figuier 1868; Pancaldi 2003, pp. 212-221). In the July number of Nicholson's Journal, ${ }^{6}$ parts of Volta's paper were cited together with a multitude of experiments already made by a variety of scientists who had obtained the description of the pile (Figuier 1868, p. 400; Pancaldi 2003, pp. 212-221).

The importance of the pile can probably not be overestimated. Several authorities have emphasized this. Heilbron (1999, p. 494) described the pile as a discovery that "opened up limitless fields", Tom Tit (alias Arthur Good) a century previously reckoned the pile to be one of the three most precious apparatuses in any curiosity cabinet (Good 1898, p. 64), and Louis Figuier, some decades before, described the implication of the pile for the decomposition of water as: "It is by the means of this instrument, with an elementary simplicity

${ }^{6}$ The Journal of Natural Philosophy, Chemistry and Arts, edited by W. Nicholson, was commonly called the Nicholson's Journal or Nicholson's Philosophical Journal. 
and a quite mediocre puissance, that Carlisle decomposed water, that is to say accomplished the most fecund of the discoveries which have been made with the pile of Volta, as it revealed equally to physics and to chemistry a horizon without limits" (Figuier 1868, p. 400).

\section{Experimenting, Re-reading, Rehearsal and Re-rehearsal}

At this point, our primary aim was to decompose water with an electric current in Gjøsteen's apparatus. The use of the voltaic pile to achieve this was initially merely subsidiary. So what happened? As the pile is so well known, we set off, to be perfectly honest, without reading Volta's paper at all. The pile is depicted in so many places; anybody knows it is sufficient to stack two types of metal plates with a humid layer in between, which we did. About 30 plates were assembled and nothing happened, not a single little bubble could be detected at the electrodes, even with a magnifying glass. We live in the twenty-first-century so a voltmeter was obtained and plainly displayed $0.0 \mathrm{~V}$. A good laboratory advice states 'if everything fails, read the manual' so we did. In Volta's letter the 'artificial electric organ', that is the pile (Volta 1800), was meticulously described and clearly we had made mistakes when unintentionally applying today's view of electrolytic cells by placing an electrolyte in between each metal disc. Taking into account the abundantly recorded Galvani-Volta controversy (e.g. de Levie 1999; Heilbron 1999; STeT 2010) in which Volta strongly adhered to the "two-conductor side" and the subsequent century-long controversy between the so-called contact theory and the chemical theory (Brockman 1928; Kragh 2002), we should have known better and immediately put the two metals in contact. But reality inside the laboratory is not characterised by strict theoretical considerations and intimate apprehension of previous literature and reports. In this respect we were guided, as many before us, by to-days chemical comprehension of galvanic cells, general intuition, and the material available and then we failed, in line with those who claim that science is more about thinking, guessing and trying things (Hodson 1991) — that sometimes work, but often fail.

We started rebuilding, and soon found ourselves entangled in the field of experimenting, where a series of decisions might determine the outcome of the experiment. In between the pairs of copper and zinc plates, a solution of imbibed materials was to be used. What material? Pieces of skin? Carton? Which type? Possibly filter paper? The size, did that matter? What about the liquid? Were we to use pure water, salt water or soapy water; and what about the concentration? There were some answers in Volta's text, yet choices and compromises were necessary.

We ended up using filter paper as this was of a suitable size, and table salt (sodium chloride) of unknown concentration, as well as an imbibition of unknown amount. According to Volta the electric energy came from the contact between the metal plates, so these needed to be in contact, which we tried to achieve by pressing the column together with appropriate, that is unknown, force. When we connected this pile to our apparatus bubbles indeed appeared; unmistakably, but minute and so slowly. The temptation to use the dry cells lying around was hard to resist as we struggled to adapt to the new time scale, but we did not waiver-initially. As it took hours and hours, we eventually went away, got distracted and forgot the whole experiment and returned the next day. What did we find? Gas had been evolved in both test tubes, but clearly the ratio between the oxygen and hydrogen gas was not 1:2, as can be seen in Fig. 2. For the next weeks we repeated the experiment again and again, varying electrode material, electrolyte, voltage, saturating the solution with the gases, etc. However we never reached a precise 1:2 ratio, although some 


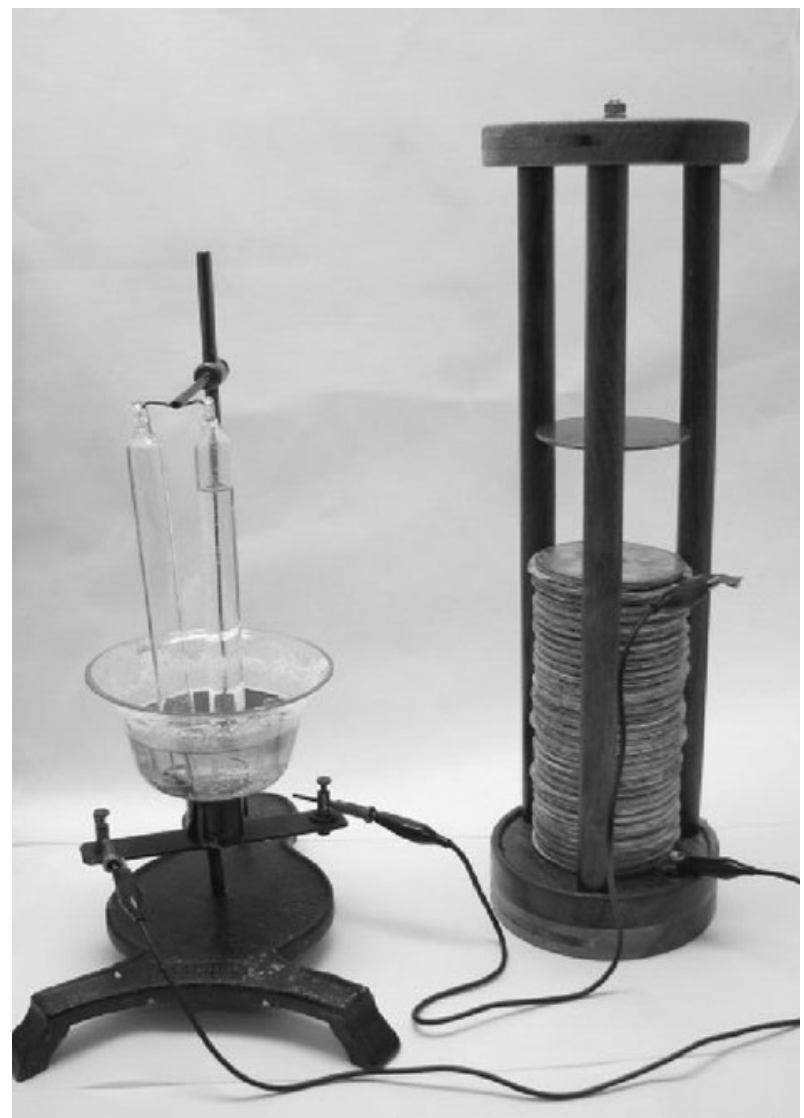

Fig. 2 Ole Georg Gjøsteen's apparatus for the decomposition of water connected to a voltaic pile. Note that the left hand test-tube is full of hydrogen, whilst the right hand test-tube is approximately $1 / 5$ full of oxygen

sources claim this is easy, but with some practice we approached this ratio. ${ }^{7}$ Then other duties called and the pile was left for some weeks before we returned. To dismantle it, we found that the most useful utensils were a hammer and chisel. The whole column had become as hard as concrete. Rereading Volta was of no help, the only problem he mentions is that of a too dry column, which he kindly suggests should be re-humidified. Our pile was put to swim in various solutions without much effect. Somehow Volta never mentions dismantling the pile, and we now understand why. ${ }^{8}$ But we wanted our students to re-build

\footnotetext{
7 Few authors today mention the deviation from the 2:1 ratio of hydrogen to oxygen gas produced, although more than century ago the textbooks and demonstration manuals (Jahn 1883; Müller 1901; Poyser 1889) tended to do so. In the last century, as well as in the present one, there are reports on this fact which is apparent to anyone actually doing the experiment (Kelsh 1985; Limón-Petersen et al. 2007; Zhou 1996). The explanations suggested are current density, voltage, absorption of hydrogen onto the Pt-electrodes, production of hydrogen peroxide at the anode, production of ozone when electric current is passing through oxygen and unequal solubility of the two gases in the aqueous solution (e.g. Kelsh 1985; Poyser 1889; Zhou 1996).

${ }^{8}$ On the other hand, W. Nicholson, when reporting on Volta's invention, mentions chemical reactions taking place within/on the pile and problems of recovering the plates. See Nicholson (1800).
} 
the column, so the metal plates had to be presented in a recognisable state. That meant, after the struggle of dismantling the pile, we had to scrape and clean the plates for days and still they were far from good-looking. This experience, however, clearly indicated one of several problems with the Volta pile. We were therefore pleased when we discovered that also Cruickshank (1801) complained about the maintenance of the pile. He then turned it on its side to form the so-called trough battery, one of the first steps in the improvement of voltaic cells (Cruickshank 1801).

\section{Premiere}

At the start of the premiere the students were urged to build the pile, without any comments from our side on what to expect, or what our experience and struggles had been-though it would be a naive to believe that our body-language did not betray us. The repetitive action of putting 60 roundels each of zinc, copper and ox skin (filter paper having been abandoned long before) on top of each other lasted for some time, creating a kind of monotonous ambience. The students had no expectations and were politely interested. When finally completed, we decided to verify the power of the pile before connecting it to Gjøsteen's water splitting apparatus. Around 1800, a prime instrument for analyzing the effect of the pile was the human body. Again we were inspired by Volta, who had applied the terminals from the pile to various parts of his body, including hands, eyes, tongue and ears. Volta reported that he could feel the incremental increase in power as new pairs of plates were added, the effect being noticeable already from 4 to 5 pairs (Volta 1800)—-this, though, we were entirely unable to discern. Again, not able to deny ourselves a voltmeter, we felt its readings almost confirmed our lack of senses. Were Volta's experimental results thus theory-laden? One should not underestimate Volta and his contemporary experimentalists' excellent senses and knowledge, and our lack of such. Nevertheless, after completing a pile of 60 units we made a ring, held hands (salt wetted) and electrocuted both the students and ourselves. The peaceful atmosphere evaporated immediately as we received shocks, which seemed to be an unevenly distributed experience, as also previously reported (Heering 2000). We then connected our pile to the water splitting apparatus and the students observed what had just previously surprised us, namely that the gas bubbles were so tiny and so few that 'time' rose to the top of the discussion themes. The gas volumes produced during the session were also so small that the students were unable to see anything approaching the 2 to 1 ratio of hydrogen and oxygen. The assembly was thus left connected so they could reobserve the experiment over the course of the next few days. Some forgot, but to those who returned, the skewed ratio was striking and challenged claims presented by teachers and textbooks during their education. As our aim had been to invite the students into an experience that had entertained us by surprising and challenging our own preconceived views, we left them cruelly to digest the idea that water during electrolysis does not split into exactly 2 volumes hydrogen and 1 volume oxygen. This fact was better known before, but is often ignored today. Nevertheless it can be verified in for example general chemistry books that include a photo, rather than a sketch, of the electrolysis of water (e.g. Tro 2008).

During the actual period of experimenting, and after "time" had been laid to rest as a discussion theme, there was also ample opportunity to question statements, descriptions and phrasing in Volta's text. Some fairly obvious ones were: Why did he construct it in the way he did? Which inspirations, struggles, previous work and other scientists was he inspired by or relied on? As we did not have much time at our disposition we restricted ourselves to one of his comments about the electric fish (the torpedo fish) and the electric eel, both 
extraordinary animals, according to several accounts. Volta actually calls his pile 'an artificial electric organ' directly inspired from 'the natural electric organ' of the electric fish or eel (Piccolino 2005; Walsh and Seignette 1773-1774). Developing this theme, Volta actually suggested that one could enclose the whole pile with a material/skin and make a well-configured head at one end and a tail at the other. Then, Volta wrote, the 'artificial electric organ' would not only resemble the electric eel internally, but also externally (Volta 1800). This seemed an attractive idea to us, but we decided the other way round, that is to investigate a 'natural electric organ'. At the local fish market we purchased an 'arctic electric eel', brought it back and started laparoscopy at an appropriate place, the flank. By enlarging the hole a bit, we got a glimpse of the inside and apparently there was something resembling pictures of 'the natural electric organ'. At that moment we felt that chemistry, biology and history were wonderfully united; indeed we experienced a temporary moment of eureka. Such transient moments are well worth cherishing, a fact any experimentalist knows, as we were soon to realise that something was wrong. Evidently our eel was not electric, and the place of our dissection was less than accurate as the electric organ is to be found close to the tail, plainly revealing our lack of biological knowledge. So one more lesson when trying to reconstruct two iconic experiments in the history of chemistry was that we and the students had to agree with the Mayor of la Rochelle, who attended experiments with the electric fish performed by Mr Welsh in 1773 and reported: "That indeed all yet done was little more than opening the door to inquiry" (Walsh and Seignette 1773-1774, p. 468).

Restaging to the students an experiment, almost in tandem with our own experiments created a far more alert and enthused teaching atmosphere than normal. Of course this does not imply that we suggest not preparing experiments or avoiding using well-established experiments for most experimental settings with students, but sometimes one must be bold.

\section{Epilogue}

There were several objectives at the outset of our reconstruction of these historical experiments using one of the modest objects in our collection, but a major one was to incorporate an experiment with a live performance for the students in our history of science course. As we had struggled and enjoyed ourselves to a far greater extent than we had anticipated through the whole process, an ownership and deeper interest had developed, which gave momentum to adapt our new knowledge for further dissemination to a broader audience. An unforeseen result is that this experiment has become a good "candidate" when receiving visiting school children. Moreover, in the enthused meeting with the youths our reconstructed experiment has corroborated its own existence.

Acknowledgments Our thanks are due to instrument-maker Egil Thorsetnes, NTNU, for making parts for our pile and to Berit Bungum for lending us her collection of physics textbooks.

Open Access This article is distributed under the terms of the Creative Commons Attribution Noncommercial License which permits any noncommercial use, distribution, and reproduction in any medium, provided the original author(s) and source are credited.

\section{References}

Arnljot, I. (1968). Fysikk for ungdomsskolen. Oslo: Cappelen.

Brockman, C. J. (1928). The origin of voltaic electricity: The contact vs. chemical theory before the concept of E.M.F. was developed. Journal of Chemical Education, 5, 540-555. 
Bruun, S. (1920). Larebok $i$ kjemi for gymnaset. Kristiania: Olaf Norlis forlag.

Bruun, S., \& Devik, O. (1965). Larebok i fysikk for realskolen. Oslo: Olaf Norlis forlag.

Buchwald, J. Z. (Ed.). (1995). Scientific practice-Theories and stories of doing physics. Chicago: University of Chicago Press.

Cavicchi, E. (2006). Nineteenth-century developments in coiled instruments and experiences with electromagnetic induction. Annals of Science, 63, 319-361.

Chang, R. (1994). Chemistry. New York: McGraw-Hill Incorp.

Corn, J. J. (1996). Object lessons/object myths? What historians of learn from things. In D. Kingery (Ed.), Learning from things: Method and theory of material culture studies (pp. 35-55). Washington, DC: Smithsonian Institution Press.

Cruickshank, W. (1801). Additional remarks on galvanic electricity. Journal of Natural Philosophy, Chemistry and Arts, 4, 254-264.

Daston, L. (Ed.). (2004). Things that talk. Object lessons from art and science. New York: Zone Books.

de Levie, R. (1999). Galvani. Journal of Chemical Education, 76, 320.

Eggen, P.-O., \& Kvittingen, L. (2004). Electrolysis of water, small-scale and low-cost apparatus. Journal of Chemical Education, 81, 1337-1338.

Faraday, M. (1849). Experimental researches in electricity. London: R. and J. E. Taylor.

Figuier, L. (1868). Les Merveilles de la Science. In F. Cardot (Ed.), Histoire de l'Électricité. Association pour l'histoire de l'électricité en France (1985), pp. 371-479.

Galison, P. (1987). How experiments end. Chicago: University of Chicago Press.

Good, A. (1898). Faksimilutgåve av Tom Tits experiment-vetenskapliga förströelser. Stockholm: Alf Samuelssons Förlag.

Hacking, I. (1983). Representing and intervening. Introductory topics in the philosophy of natural sciences. Cambridge: Cambridge University Press.

Heering, P. (2000). Getting shocks: Teaching secondary school physics through history. Science Education, 9, 363-373.

Heering, P., Rieß, F., \& Sichau, C. (Eds.). (2000). Im Labor der Physikgeschichte. Zur Untersuchung historischer Experimentalpraxis. Oldenburg: BIS Verlag.

Heideman, S., \& Wollaston, G. (1986). The electrolysis of water: An improved demonstration procedure. Journal of Chemical Education, 63, 809-810.

Heilbron, J. L. (1999). Electricity in the 17th and 18th centuries. A study of modern physics. New York: Dover Publications Inc.

Hildebrand, G. F. (1805). Annalen der Physik, Gilberts Annalen, Leipzig. 257-262.

Hodson, D. (1991). Practical work in science: Time for a reappraisal. Studies in Science Education, 19, $175-184$.

Holmsen, H., \& Strøm, E. (1942). Naturlare for folkeskolen. Oslo: J. W. Cappelens forlag.

Holtsmark, G. (1925). Naturlare for millomskulen. Oslo: J. W. Cappelens forlag.

Jacobsen, N. (1903). N. Jacobsen's Elektriske Verksted's illustrerte katalog no. 2; Fysiske apparater.

Jahn, H. (1883). Die Elektrolyse und ihre Bedeutung für die theoretische und angewandte Chemie. A. Hölder.

Jansen, O., \& Eskeland, S. (1940). Larebok i fysikk for ungdomsskolen. Oslo: Olaf Norlis forlag.

Jansen, O., \& Eskeland, S. (1946). Larebok i fysikk. Oslo: Olaf Norlis forlag.

Kåsa, J. S., \& Strøm, O. (1939). Fysikk og kjemi for folkeskolen. Oslo: J. W. Cappelens forlag.

Kelsh, D. J. (1985). Water electrolysis-A surprising experiment. Journal of Chemical Education, 62, 154.

Kohl, M. (1926-1928). Max Kohl A. G. Preisliste Nr. 100, Band I-III Unterrichts- und Laboratorienmöbel. Physikalische Apparate. Chemnitz: Max Kohl A. G.

Kragh, H. (2000). Confusion and controversy. Nineteenth-century theories of the Voltaic pile. In F. Bevilacqua \& L. Fregonese (Eds.), Nuova voltiana. Studies on volta and his times (Vol 1, pp. 133-157).

Levi, P. (1989). The periodic table. London: Abacus.

Leybold's Nachfolger, E. (1913). Einrichtungen und Apparate für den physikalischen Unterricht sowie für Übungen im Praktikum nebst Literaturangaben. Cologne: Paul Gehly.

Limón-Petersen, J. G., Gutiérrez-Murillo, H. F., Flores-Saiffe, B., \& Ibanez, J. G. (2007). A derivative method for the estimation of the electrochemical production rates of ozone in sulfuric acid. ECS Transactions, 3, 29-35.

Lourenço, M. C. (2005). Between two worlds: The distinct nature and contemporary significance of university museums and collections in Europe. $\mathrm{PhD}$ thesis, Conservatoire Nationale des Arts et Métiers, Paris.

Müller, F. C. G. (1901). Ein neues Knallgasvoltameter. Zeitschrift für den physikalischen und chemischen Unterricht, 14, 140-143.

NBL. (1929). In E. Bull, E. Jensen (Eds.) Norsk biografisk leksikon (pp. 492-494). 
Nicholson, W. (1800). 'Account of the new electrical or galvanic apparatus of sig. Alex. Volta, and Experiments performed with the same. Journal of Natural Philosophy, Chemistry and Arts, 4, 179-187.

Pancaldi, G. (2003). Volta, science and culture in the age of enlightenment. Princeton, Oxford: Princeton University Press.

Piccolino, M. (2005). From an ambiguous torpedo to animal and physical electricity. Audiological Medicine, $3,124-132$.

Pickering, A. (Ed.). (1992). Science as practice and culture. Chicago: University of Chicago Press.

Poyser, A. W. (1889). Magnetism and electricity-A manual for students in advanced classes. London, New York, Bombay: Longman Green \& Co.

Rheinberger, H.-J. (1997). Towards a history of epistemic things. Synthesizing Proteins in the Test Tube. California: Stanford University Press.

Shapin, S., \& Schaffer, S. (1985). Leviathan and the air-pump: Hobbes, boyle, and the experimental life. Princeton, NJ: Princeton University Press.

Sibum, O. (2000). Experimental history of science. In S. Lindqvist (Ed.), Museums of modern science. USA: Science History Publications.

STeT. (2010). Science teacher e-teaching http://stet.wetpaint.com/page/Volta\%2C+Galvani+and+animal+ electricity. Accessed July 2, 2010.

Sverre Bruun og Olaf Devik-et lærebokjubileum (1964) Olaf Norlis forlag, Oslo.

Tro, N. (2008). Chemistry—A molecular approach. Upper Saddle River, NJ: Pearson/Prentice Hall.

Troostwyk, A. P. V., \& Deiman, J. R. (1789). 'Sur une manière de décomposer l'Eau en Air inflammable et en Air vital. Observations sur la physique, sur l'historie naturelle et les arts, 35, 369-378.

Volta, A. (1800). On the electricity excited by the mere Contact of conduction Substances of different kinds. Philosophical Transactions of the Royal Society of London, 90, 403-431.

Walsh, J., \& Seignette, S. (1773-1774) Of the electric property of the Torpedo. Philosophical Transactions of the Royal Society of London, 63, 461-480.

Wittje, R. (2003). Accoustics, Atom Smashing and Amateur Radio: Physics and Instrumentation at the Norwegian Institute of Technology in the Interwar Period. Dr. philos thesis, Norwegian University of Science and Technology, Trondheim.

Wittje, R. (2006). Foundation of N.T.H. in 1910 in international context. In R. Sigmund-Schultze \& H. K. Sørensen (Eds.), Perspectives on Scandinavian science in the early twentieth century (pp. 111-132). Oslo: Novus Forlag.

Zhou, R. E. (1996). How to offer the optimal demonstration of the electrolysis of water. Journal of Chemical Education, 73, 786-787.

Zumdahl, S. S. (2003). Chemical principles. Boston, New York: Houghton Mifflin Co. 